\title{
Reading Between the Lines: Intra-Group Heterogeneity and Conflict in Sri Lanka
}

\author{
Kenneth D. Bush ${ }^{1}$
}

\begin{abstract}
We are working on borrowed time in the political space temporarily opened up by the reports of the various human rights missions [that have visited Sri Lanka] in the past year.
\end{abstract}

\section{-Colombo-based human rights worker, 1992}

\section{Introduction}

Even a cursory glance at the history of refugees reveals a connection between mass violence and the creation of large refugee populations. However, the experience of Sri Lanka underscores the need to disentangle the nature and implications of this connection. In Sri Lanka, different communities have been affected and displaced in response to changes in the dynamics of violence: in the late 1970 s and early 1980 s, mob violence in the Hill Country forced thousands of Plantation Tamils to seek refuge in the Northern Province and in southern India; from 1987 onwards, military offensives by the Indian Peace Keeping Force (IPKF) and later the Sri Lankan Army displaced Tamils from the Northern and Eastern provinces, many of whom found their way to India, Europe and North America. More recently, the tactical use of massacres by all combatant groups in the Eastern province generated a stream of internally displaced Muslims as well as Tamils. ${ }^{2}$ The bottom line is that in a country with an estimated population of 17.5 million, there are more than a million displaced people-the majority of whom are from the Tamil community. 3

The starting point for developing an understanding of conflict in Sri Lanka must be the recognition that the major

\footnotetext{
Kenneth D. Bush is currently writing his doctoral dissertation, "Peering Over the Edge: the IntraGroup Dimensions of Inter-Group Ethnic Conflict," in the Government Department and Peace Studies Program at Comell University.
}

groups are internally divided into politically salient subgroups along a range of differentiating axes such as regional identification, religion, language, caste, political ideas and class. This approach stands in contrast to the representation of the conflict as the stark and violent confrontation between the Tamils and the Sinhalese. This article rests on the belief that to make sense of the patterns of ethnic violence, it is necessary to delve more deeply than the interaction between warring ethnic groups; it is essential that the structure and dynamics within the groups in conflict assume a central position in analysis. It would appear that the intransigence, intensity and insolubility of some cases of violent ethnic conflict may be less a consequence of the polarization of groups than a function of the splintering and warring of factions within factions.

The systematic examination of the impact of fluctuating violence on refugee flows in Sri Lanka and elsewhere has implications for the development of practical early warning capabilities concerning refugees and displaced persons. It also has implications for efforts to manage and settle such conflicts. Drawing on recent fieldwork, this article attempts to contribute to this examination by providing a current snapshot of the various Tamil groups in Sri Lanka in the context of changing patterns of violence.

\section{Intra-Group Divisions of the Tamil Community}

Our examination of the intra-group divisions of the Tamil community is made easier by a geographical correspondence to major social, political and economic differences between groups. Accordingly, we may identify the following principal subgroups: Colombo Tamils, Jaffna or Northern Tamils, East Coast Tamils and Plantation Tamils. Not surprisingly, within each of these groups there are further subdivisions and systems of stratification and differentiation (for example, caste, economic and social class, and political allegiance). While recognizing the political salience of each of these subsequent axes of differentiation, this article privileges geographical categorization because in Sri Lanka, where one lives is central to the understanding of who one is. Or, as Jonathan Spencer puts it, "identity is a matter of belonging to place as much as having a history." This is particularly important in the context of the current discussion because the patterns of violence and displacement are fundamentally rooted in "where one lives." Thus, for example, in 1991 the U.S. Committee for Refugees reported that in the Northern and Eastern provinces one in five residents has been displaced by the violence.

Members within these Tamil subgroups recognize a status hierarchy that conditions intra-group relations: $\mathrm{Co}$ lombo Tamils and Jaffna Tamils place themselves on top, East Coast Tamils are located in the middle and the Plantation Tamils are at the bottom. ${ }^{5}$ This division is further underscored by many East Coast Tamils' distrust of the economic domination by Jaffna Tamils. ${ }^{6}$ It is ironic that while cultural differences and natural antipathies between the East Coast Tamils and Jaffna Tamils once may have encouraged each to pursue a separate political agenda, the government's heavy-handed military actions appearto have helped to push these two groups closer together. Similarly, this appears to have contributed to making the East Coast Tamils more receptive to the most powerful Tamil paramilitary, the Liberation Tigers of Tamil Eelam (LTTE)-despite the Jaffna Tamil complexion of the organization.?

The great social distance between the Plantation Tamils and the other Tamil communities is reflected by a project ini- 
tiated in the 1970s by the late Bishop Leo Nanayakkara to educate Jaffna Tamils about the poverty-stricken plight of Plantation Tamils. He was struck by two observations: 1) the Jaffna Tamils' lack of awareness concerning the conditions on the tea plantations; and 2) the low regard in which Plantation Tamils were held by Jaffna Tamils. This latter point is frequently reflected in the Jaffna Tamils' use of "low Tamil" when addressing Plantation Tamils. Unfortunately, political events eventually buried this project.

For the purposes of this article, the anthropological details of such divisions and stratification are less important than the fact that they exist and are politically salient in conditioning the behaviour of the members of these sub-groups. The remaining sections of the article will situate the intra-group divisions more explicitly in the context of violence and the displacement of people.

\section{Internecine Feuding}

The feuding among Tamil paramilitary groups is an especially bloody manifestation of one axis of division within the Tamil community. ${ }^{8}$ Feuding between the major Tamil paramilitaries (particularly the LTTE, EPRLF, TELO, and PLOTE) ${ }^{9}$ has been a common feature of paramilitary politics since the creation of these groups in the late 1970s and early 1980 s at times even spilling into the streets of South India. Violence became especially vicious following the gradual IPKF withdrawal from the Northern and Eastern provinces in 1989.

This created a power vacuum and provided the structural incentives for the paramilitaries to intensify their battle for territorial control of the traditional Tamil regions. The groups were also fighting to militarily win the right to represent the Tamil people in the eyes of both Tamil and Sinhalese constituencies. In the context of thecurrent discussion, it should be noted that the withdrawal of the IPKF and subsequent reassertion of LTTE territorial control in the north and east sent many EPRLF supporters and government collaborators (voluntary and nonvoluntary) fleeing LTTE retribution. ${ }^{10}$ This was reflected in a surge of applications for refugee status in Canada and elsewhere. ${ }^{11}$

To compete with the battle-hardened and militarily superior LTTE, the other Tamil paramilitaries have attempted to draw resources from the Sri Lankan and Indian governments. Indeed, all major Tamil paramilitaries (TELO, PLOTE and EPDP) $)^{12}$ are now allied alongside the Sri Lankan military against the LTTE. The paramilitary cleavages appear to have been adroitly harnessed by both the IPKF and the Sri Lankan Army to pit Tamils against Tamils. At times, the government's manipulation of paramilitary animosities has subsidized the violence in unexpected ways. For example, the unsuccessful impeachment proceedings against President Premadasa in September 1991 produced well-founded allegations that he was responsible for providing the LTTE with arms and supplies for use against the IPKF and the India-backed Tamil National Army (TNA) in November $1989^{13}$ (Incidentally, these same supplies are now being used by the LTTE against the Sri Lankan Army, East Coast Muslims, Tamil civilians, pro-government Tamil paramilitaries and Sinhalese settlers in the North). It would appear that the presi- dent was attempting to capitalize on the divisions between the Tamil paramilitaries in order to buttress his political position from challengers within the Sinhalese political arena. That is, covert support to the LTTE allowed him to circumvent the constraints of the 1987 India-SriLanka Agreement in an attempt to push the IPKF off the island. If successful, Premadasa would have been able to defuse a serious challenge from opponents that coalesced around the issue of expelling the IPKF. Interestingly, despite Sinhalese heterogeneity, the Agreement succeeded in rallying and aligning a diverse range of groups: political partiesled by theopposition SLFP(Sri Lanka Freedom Party), community groups, the media, academics, segments of the Buddhist clergy, and Sinhalese cultural and Buddhist patriotic organizations. Perhaps most dangerously, it provided a lightening rod to mobilize the discontent of the unemployed Sinhalese youth which was ultimately expressed in the Peoples' Liberation Front (JVP) insurrection of 1988-89.

Similarly, despite the alliance of the EPRLF and PLOTE with the Sri Lankan military, there are strong allegations that Colombo previously provided support to the LTTE for its feud against the progovernment Tamil paramilitaries. ${ }^{14}$ At one level of analysis, the feuding is rooted in intra-group power politics. But at another level, the feuding is exacerbated by the rivalry between Colombo and Delhi. In the latter regional context, intra-group feuding assumes the features of a war by proxy-with Delhi backing the EPRLF and the TNA and Colombo backing (however counterintuitively) the LTTE.

\begin{tabular}{|c|c|c|c|c|c|c|c|c|}
\hline \multirow[b]{2}{*}{ District } & \multirow[b]{2}{*}{ Jaffna } & \multicolumn{2}{|c|}{ Northern Province } & \multirow[b]{2}{*}{ Mannar } & \multicolumn{3}{|c|}{ Eastern Province } & \multirow{2}{*}{$\begin{array}{l}\text { National } \\
\text { Average }\end{array}$} \\
\hline & & Mullaitivu & Vavuniya & & Trincomalee & Batticaloa & Amparai & \\
\hline Sinhalese & 0.6 & 5.1 & 16.8 & 8.1 & 33.6 & 3.2 & 37.6 & 74.0 \\
\hline Sri Lankan Tamil & 95.3 & 76.0 & 56.9 & 50.6 & 33.8 & 70.8 & 20.1 & 12.6 \\
\hline Indian Tamil & 2.4 & 13.9 & 19.4 & 13.2 & 5.6 & 1.2 & 0.4 & 5.6 \\
\hline Muslim & 1.6 & 4.9 & 6.9 & 26.6 & 29.0 & 24.0 & 41.6 & 7.1 \\
\hline Other & 0.1 & 0.1 & 0.02 & 1.5 & 1.0 & 0.8 & 0.3 & 0.7 \\
\hline
\end{tabular}

Source: Government of Sri Lanka Census 1981 
This paramilitary feuding has implications for both current and future patterns of conflict in the North and East. The Tamil paramilitary coalition against the LTTE is very clearly a coalition of convenience rather than commitment. It has been maintained by the organizational glue provided by Delhi and Colombo and by the common understanding among the militants that they are threatened by the LTTE. If the LTTE threat is weakened or removed, the unravelling of the coalition will likely follow and the conveniently overlooked intra-paramilitary tensions and conflict will spill into more violent feuding in the North and the East-and perhaps even into the streets of Colombo since that is where pro-government Tamil paramilitaries located their offices. ${ }^{15}$ The July 1989 murder in Colombo of the leader of the democratically-elected Tamil United Liberation Front (TULF) -allegedly by the LTTE-may presage things to come.

The fuelling of intra-group antagonism by Colombo and Delhi for shortterm, short-sighted political goals contributes to the brutalization of civilians in the North and East and will inhibit (or at least complicate) movement towards accommodation in any effort to construct a postwar settlement.

\section{Tamil-Muslim Relations on the East Coast}

The sensitive demographic balance on the East Coast is a crucial difference between the Northern and Eastern provinces-a difference that has been reflected in the dynamics of violence and the displacement of persons. While the northern Tamils clearly constitute the majority group in the Northern Province, the demographic dominance of Tamils is far less secure in the Eastern Province where Muslims find themselves pivotally placed in a precarious ethnic balance (see Table 1). ${ }^{16}$ There the Muslims can substantially help or hinder either Támil or Sinhalese efforts to capture political and military control. Consequently, they have been variously wooed and attacked by militaries and paramilitaries on all sides.

Until recently, relations between East Coast Tamils and Muslims fluctuated between cooperation and conflict, depending on the political context. Because of the Muslims' strategic position in the demographic balance, they have tended to support whichever political or military group seemed best able to secure or protect their interests. It should be emphasized that despite a common language, the two groups are clearly separated on the basis of religion. ${ }^{17}$ Surprisingly, in the past there has been sufficient common ground to encourage a number of Muslims to join the LTTE. ${ }^{18}$ This fact should not suggest that the East Coast Muslim and Tamil political projects are one and the same; but it does illustrate the variable and nuanced relationship between the two groups. However, since June 19.90 the two communities are being violently separated as a result of the LTTE campaign to isolate Muslims out of the region. The motives underpinning the LTTE version of ethnic cleansing remain unclear. Nevertheless, in October 1990, the LTTE banished all Muslims living in the northern districts of Mannar, Mullaitivu, Kilinochchi and Jaffna with the order to "leave or be killed." Some villages were given as little as two hours to quit their homes. ${ }^{19} \mathrm{~A}$ consequence of this strategic shift in relations between the LTTE and the Muslims is the massive exodus of Muslims from the East Coast. It is estimated that approximately 60,000 evicted Muslims from these northern districts fled south seeking refuge. In July 1991, it was estimated that 40,000 Muslims were living in some sixty camps in Puttalam District. The Muslim Refugee Rehabilitation Organization estimated that at that time there were more than 100,000 displaced Muslims in Sri Lanka. ${ }^{20}$ By September 1992, it was reported in The Island International that some 150,000 Muslims were displaced from the North. ${ }^{21}$

The Sri Lankan government has always been aware that a coalition of Muslims and Tamils on the East Coast could effectively challenge Colombo's authority. Thus, the government has employed a two-pronged strategy to lessen this possibility. First, it has attempted to alter the demographic composition of the East Coast by increasing Sinhalese settlement in and control over traditional Tamil ar- eas. This so-called "West Bank scheme" envisions the resettlement of thousands of armed Sinhalese settlers trained in selfdefence on government-owned land in this area. ${ }^{22}$ By 1985 , over 50,000 Sinhalese (ex-convicts, retired military personnel and families displaced by the massive Mahavelli water project) were resettled on traditional Tamil land. Unable to affect the government's colonization policy, some Tamil paramilitaries responded with terror and violence against these settlements-including the wholesale massacre of communities, such as the Dollar and Kent Farm massacres in 1984.

The second part of Colombo's strategy has been to encourage the separation of Muslim and Tamil interests and identities. Education policy was conveniently pressed into service to allow Muslim children to study in "Muslim schools" (until 1974), which helped to emphasize religious differences while deemphasizing the shared Tamil language. The establishment and expansion of these schools, it must be emphasized, vitiates the principle of nonsectarian state education, which has been the declared policy of all governments since 1960.23

Schisms are appearing within the Muslim community. The Sri Lanka Muslim Congress (SLMC), the first explicitly Muslim political party, was created to represent Muslim interests. However, it has been hindered by the debate over who or what constitutes the "Muslim voice" and its subsequent poor showing in the May 1993 Provincial Council election suggests diversity rather than unity. Furthermore, young Muslimsin Sinhalaspeaking areas of the country are reported to be losing their ability to speak Tamil to their co-religionists on the East Coast, thus suggesting the beginnings of a linguistic as well as a regional divide among the Muslim community. ${ }^{24}$

Especially effective in separating Muslims and Tamils on the East Coast was the Sri Lankan government's decision to create and arm a Muslim civilian militia (the Muslim Home Guard) ostensibly for community protection. Meanwhile, Tamil villages are unarmed and unprotected. As far as self-protection is 
concerned, the Muslim Home Guard appears more likely to be involved in the massacre of innocent Tamil children, women and men than in the protection of Muslim communities. The consequence of this government policy has been the provision of the material means to militarily pit Muslim groups against Tamil groups. The victims, by and large, are the innocent civilians caught in the middle. This is graphically evident in the increasing use of massacres by all combatant groups in Sri Lanka.

\section{The Tactical Use of Massacres}

The Welikande massacre of 162 people illustrates the dynamics of this type of violence. At the end of April 1992 in the Muslim village of Alinghipotana, the Muslim Home Guard fled into the jungles when the village was attacked by thirty to forty armed men who were believed to be members of the LTTE. Twenty peoplewere injured and seventy four people were murdered including five babies and twenty-eight school children; most were stabbed or hacked to death. A few hours later, the Muslim Home Guard left the jungle and teamed up with some Muslim policemen to launch its own massacre on the Tamil village of Muthugala. Fifty people were murdered and sixteen were injured. The slaughter continued in the Tamil village of Karapola-thirty-eight people were murdered including six children. Fiftynine were injured. ${ }^{25}$

This incident reflects an especially brutal violence on the East Coast; one that is likely to continue festering for a number of reasons. The location of such villages in the "interface" between the Tamil north and the Sinhalese south places them on the front line in the battle for control of both territory and the "hearts and minds" of villagers. The disintegration of the rule of law in the country as a whole, and the failure to hold combatants accountable for their actions in the war zone (reflected in the systematic and pervasive human rights abuses by all forces) leave villagers open to continued abuse and intimidation. The most likely reason for the continuation of such massacres is that both pro-government and LTTE forces appear to have adopted military strategies designed to pursue their battle for territorial and political control through intimidation and terror. Massacres have become part of the military repertoire for all combatant groups in the North and East. ${ }^{26}$

It is impossible to ensure the security of thousands of villagers in the midst of ongoing war. As in Yugoslavia, civilians are not simply caught in the crossfire, they have become targets. ${ }^{27}$ Massacres are orchestrated to push people out of strategic areas and to create inter group enmity in order to inhibit the development of inter-group coalitions that might challenge the warring factions or the legitimacy of violence. While such atrocities may be instrumentally employed by group leaders, the barbarism is as much a consequence as a cause of the conflict.

Even more prevalent than the massacres are widespread disappearances and increasing vigilantism. From June 1990 to September 1991, on the East Coast, Amnesty International reported that over 3,000 Tamil people "disappeared" while in the custody of government forces. ${ }^{28}$ By June 1992, the Missing Persons Project of the Batticaloa Peace Committee had a growing list of 3,600 names for the Batticaloa area. Especially embarrassing for the Premadasa regime are the recent allegations by Premadasa Udagampola, the former deputy inspector of police, that the United National Party (UNP) government of Premadasa employed its own vigilante squad called the "Black Cats" to murder opponents, including members of the official opposition party, the Sri Lankan Freedom Party..$^{29}$

Until there is a lasting political solution, innocent villagers will continue to be brutalized, displaced and killed. Yet, even if a political solution was worked out, the most daunting obstacle to peace would be the traumatic legacies of dehumanization and distrust. ${ }^{30}$

The direct consequence of such violence in the North and East has been the massive dislocation of thousands of Tamils and Muslims. Many internally displaced people have found themselves in and around Colombo. A pressing question for many outside observers and agencies concerns the safety of Tamils in
Colombo-both newly arrived and permanent residents. The following section addresses this question.

\section{The Situation of Tamils in Colombo}

Depending on who one talks to, the situation for Tamils in Colombo ranges from "perfectly fine" to "dangerously unsafe." However, those who work with refugees tend to argue that Colombo is not a safe haven for displaced Tamils or an "internal flight alternative." The official number of Tamil refugees in Colombo is $11-12,000$. But these numbers are considerably underestimated because the government stopped registering displaced peoples in November 1990. One human rights worker estimated that there were between 16-17,000 displaced Tamils in camps around Colombo, with the average camp holding 600-1000 inmates. In three camps visited by the U.S. Committee for Refugees in May 1991, 2030 percent of the residents were unregistered. The impact of non-registration of persons both outside and inside camps is two fold: it makes it difficult to calculate the number of people displaced by the war, and those who are not officially registered by the government are not entitled to food rations.

The Tamil camps in Colombo consist primarily of East Coast Tamils. ${ }^{31}$ One human rights worker explained that this is "because Jaffna Tamils, by and large, always seem to have an out." They have the international contacts and linkages that seem to enable them to leave the country. This observation should not be taken to imply that those groups with access to international networks are not legitimate refugees. But, it does point to a particular catch-22 of the refugee determination process: those individuals who might most legitimately and accurately be identified as refugees, according to even the most stringent definition, may be those who are least able to petition for refugee status. Further discussion of the situation of displaced Tamils in camps around Colombo lends support to this suggestion.

Although the displaced persons camps are the responsibility of government authorities (such as the Ministry of 
Social Services and the Ministry of Rehabilitation and Reconstruction), the help of a pro-government Tamil paramilitary, the EPDP, has been harnessed to administer and police the camps. By all accounts, the EPDP maintains oppressively tight control within the camps. It suppresses all "political talk" and has been known to kidnap and murder individuals to enforce its control. In a recent case, a Colombo-based human rights group was actively involved in negotiating the release of a boy who was kidn pped from a camp by the EPDP. The oy eventually reappeared on the East Coast in Batticaloa, an area where the EPDP is militarily active. Despite the successful retrieval of the boy, he was described as having been "hollowed out" psychologically, emotionally and spiritually as a result of torture. ${ }^{32}$ It would appear that intimidation and terror is a central element of EPDP control in the camp. As well as restricting activities within the camp, the EPDP also restricts the movement of people out of the camp by imposing an inhibitive bureaucratic process. Only recently has the role of the EPDP in the security network attracted public notice when it was reported that the inspector general of police stated that he had no control over the EPDP. ${ }^{33}$

It is interesting to note that displaced Tamil women are allowed somewhat easier access to the few activities available on the outside (such as training in "traditional women's skills" like sewing and typing). This is because prevailing cultural attitudes do not immediately cast women - even Tamil women-as a potential political threat. Unfortunately, for both economic and security reasons, these newly acquired skills are not generally put to use outside of the camp. The economic disincentive is that even if campTamils managed tosecure employment on the outside, the EPDP levies a very heavy "tax" on the earnings (as high as 50 percent). ${ }^{34}$

The security disincentives for not venturing from the camps are even more constraining. During the height of the second JVP insurrection (1987-90) all urban residents in Sri Lanka had to register at the local police stations in their neighbourhoods. There was a tight network to enforce this control. For example, landlords were responsible for ensuring that all tenants were registered at the police station (this required character statements from the police station in the hometowns of the tenants-obviously, a difficult requirement for those fleeing violence). While this government directive has recently lapsed, it has been reformulated to apply only to landlords in Colombo who want to keep Tamil tenants from the North or the East. ${ }^{35}$ Furthermore, anonymous phone calls and letters frequently draw the authorities' attention to "visitors" and strangers from outside. This is one form of control that discourages displaced persons from straying from the camp.

There are also frequent cordon and search round-ups in and around $\mathrm{Co}-$ lombo where there are even more problems for those who are not where they are supposed to be. ${ }^{36}$ The frequency of the round-ups and detentions depends on triggering events (such as assassinations and explosions) and the general political climate. These round-ups affect both long-time residents and displaced Tamils. ${ }^{37}$ Everyone is collected and detained under the Prevention of Terrorism Act. One human rights worker estimated that the typical minimum detention is ninety days. And in jails, as one human rights worker explained, beatings are routine. Because everyone from an area is rounded up, there is often no one on the outside to exert external pressure for release. When an employee for a Colombo-based human rights organization was rounded up and detained, it took tens days to gain release-and that was the result of a concerted effort by a human rights group! The process is even more protracted for an intimidated ordinary citizen. The bureaucratic and political obstacles to gaining release are formidable and recent amendments to the emergency regulations have not substantially improved the situation. ${ }^{38}$

It is very important to emphasize that those detained by government forces may be held in any place designated by the secretary to the Ministry of Defence and that the officers in charge are not required to inform magistrates or anyone else that they have in custody per- sons arrested under emergency regulations. This has contributed to the masking of human rights abuses. ${ }^{39}$

A Tamil in Colombo is at risk of being "detained" not only by the official security forces but also by the pro-government Tamil paramilitaries. While the risk of being detained by the Tamil paramilitaries remains lower than that of being detained by the police and government forces, it remains a group-specific risk nonetheless and contributes to the sense of insecurity of Tamils in Colombo (as well as other parts of the island, particularly Batticaloa and elsewhere on the East Coast). Although the pro-government Tamil paramilitaries have no legal authority to detain and arrest people in Colombo, it appears to be accepted by the authorities. As the leader of one progovernment Tamil paramilitary explained, "Yes, of course thisisillegal" but "it is common practice and accepted." The Tamils will not go to the police because "they know what the next action will be": "We'll just shoot somebody, or somebody will be missed from their family." This was all explained as part of the commonplace daily activities within a system animated by "everybody [being] afraid of everybody." The Tamil paramilitaries claim to either "settle" the problem themselves or to deliver those they have abducted to the police. There is some informal cooperation and coordination between the pro-government Tamil paramilitaries in the event that one group mistakenly arrests a member of another group. "Cordial" arrangements are made to release the detainee. Most noteworthy is how common and accepted this type of activity is. This further suggests the disintegration of the rule of law and the prevalence of intimidation as a common form of social control.

Thus the displaced Tamils in Colombo face a dead end at every turn: they are at risk in their home provinces; they are at risk in Colombo, and they are at riskin the camps. Although camp Tamils appear to be a group at risk, there are few avenues open for them to get out. Ostensibly, passports are available from local city halls (kachcheris), but in order to get a visa, one has to journey into Colombo. Yet the group-specific restrictions noted

Refuge, Vol. 13, No. 3 (June 1993) 
earlier penalizes Tamils from all subgroups and further puts them at risk. Thus, they are often afraid to come to Colombo and are unable to stay the amount of time that it takes to get a visa; another door is closed.

\section{Plantation Tamils}

Like other groups of Tamils, the Plantation Tamils have been displaced by successive waves of communal violence. The postelection riots in 1977, as well as the violence against the Plantation Tamils in 1980 and 1981, sent many seeking refuge in Vavuniya and other northern districts. A number of Sri Lankan observers reported that this helped to facilitate tentative contact between Plantation Tamil youths and some of the Tamil paramilitaries, such as PLOTE and EROS - contact that has not yet resulted in any type of concerted action or cooperation. It was not until the 1983 violence that displaced Plantation Tamils began seeking refuge in South India from the violence. It has been estimated that in 1983, two-thirds (approximately 20,000) of those Tamils who sought refuge in Tamil Nadu were Plantation Tamils from the Kandy and Nuwara Eliya regions. ${ }^{40}$ It is important to note that the violence that has displaced Plantation Tamils has been that of rioting mobs rather than that of Tamil paramilitaries and government forces. Thus in recent years this group has not suffered the same type of dislocation as those in the North and the East. Political powerlessness and social and geographical separation from other Tamil groups have tended to cast Plantation Tamils into the political backwater. However, changes within that community may soon increase politicization and volatility.

Changes within the Plantation Tamil community that are altering the politics of identity include increasing literacy, education and political awareness. These changes are reflected in the shifting political demands of Plantation Tamils from issues of citizenship and labour to issues of political representation and governance. The emergence of a Plantation Tamil political movement called the Up Country Peoples' Front (UCPF), led by the now imprisoned P. Chandra- sekaran, is a recent development that presages political mobilization. The significance of the UCPF lies less in the organization per se than in the internal social changes noted earlier that have made this development possible. As one researcher noted, "in the course of my research, I have met ten Chandrasekarans." One community worker predicted that it will be the next generation of Plantation Tamil youths - those who are educated and unemployed-that will be the basis of the politicization of the Plantation Tamils interests.

In the mid-to late 1980 s there were tentative efforts by Northern Tamil militant groups to enlist Plantation Tamil youths into the broader Eelam struggle. Indeed, Chandresekaran contested the 1989 elections under the PLOTE banner. Such contacts have been relatively lim. ited and results have been minimal. Nonetheless, the government's fear of such infiltration has recently led to mass arrests of Plantation Tamils by police in theHill Country. ${ }^{41}$ The hitherto failure of Northern militant efforts to expand the Eelam struggle into the plantation areas suggests the fundamental social tension between the Northern Tamil and Plantation Tamil political projects. Ironically, the more severe the crackdown on the alleged political activities of the Plantation Tamils, the more likely it may be that they will respond to Northern Militant overtures. Indeed, despite the apparent incongruity of the arrangement, a number of Plantation Tamils teamed up with the Marxist Sinhalese JVP during the terror of the 1987-89 insurrection. Clearly, political convenience may go a considerable distance towards blending the ostensibly incompatible. ${ }^{42}$

Many of the "new" political voices among the Plantation Tamils arise from the disgruntlement with the inability of the Ceylon Workers' Congress (CWC), the largest Plantation Tamil trade union, to "deliver the goods." In the past, political dissent and demands could be pacified or defused by the adroit manoeuvring of the leader, UNP MinisterS. Thondaman, which included cracking down on opposing unions as well as delivering significant political gains on paper, such as citizenship for those Plan- tation Tamils who were disenfranchised after independence. However, the advanced age of $\mathrm{Mr}$. Thondaman (now eighty-one years old) has given rise to jostling for leadership within the CWC. His eventual death will set in motion a battle for succession and will remove an element of stability within the Plantation Tamil areas. At this stage, a struggle for political control will likely take place both within the CWC and among the political groups in the Hill Country. This struggle need not necessarily be violent, and it need not attract the mobilized violence of Sinhalese chauvinists, but the destabilization will provide convenient points of access for those with political scores to settle.

\section{Conclusion}

The situation is potentially dangerous for all Tamil groups in Sri Lanka. Tamils in the North and East are increasingly subjected to systematic abuses by all combatant groups. As one former military officer put it, such atrocities are justified by "the necessity of authoritarianism in the face of crisis." A similar sentiment is reflected in the statement by a highly placed government official: "any solution must begin with the total military annihilation of the LTTE." Further, those Tamils and Muslims who have already been displaced by the violence are still in potential danger. Those in camps are still subject to abuse. As for the plantation areas, political rumblings suggest that the flare-up in labour violence is a real possibility in the wake of the inevitable exit of Thondaman who has provided a degree of stability through his leadership of the Ceylon Workers Congress.

While the focus of this article on the Tamil community is in keeping with the theme of this issue, a complete understanding of the conflict clearly requires the incorporation of the Sinhalese community into the intragrouplevel of analysis. The recent assassinations of President Premadasa and his political rival, Lalith Athulathmudali, only underscore the need to examine the impact of Sinhalese intra-group politics on inter-group conflict. The immediate future of SinhaleseTamil relations will be indelibly affected 
by the outcome of power struggles currently taking place within the Sinhalese arena. There is a looming danger that the jostling for position in Colombo may encourage some political entrepreneurs to play the chauvinist card (i.e., encourage anti-Tamil sentiment) in order to consolidate internal support. While the absence of anti-Tamil riots in the wake of Premadasa's assassination was welcomed with relief by all observers, there remains considerable uncertainty as to the way in which the new president, D.B. Wijetunge, and his prime minister, Ranil Wickremasinghe, will choose to address Tamil grievances and the festering violence in the North and the East. A host of factors adds to the uncertainty. The leading political parties are riven with competing factions. While the leaders of the JVP have been killed, the root causes that precipitated the insurrections of 1971 and 1987 remain unaddressed (especially youth unemployment and political disillusionment). And particularly ominous in the midst of this political turmoil is the issue of the future role of the military in Sri Lankan politics; its leadership has been decimated by assassinations and the loyalty of its troops is open to question. ${ }^{43}$

The immediate future does not look especially promising. Yet, I will conclude somewhat optimistically with a passage from a story told to me by a community worker in a war-torn area:

After the spray of machine gun-fire, the ragged and pock-marked wall was left unplastered for about a year. During that time a small sparrow decided to make one of the bullet holes its home. It pecked and picked the loose plaster away, eventually dislodged the slug and made a tiny nest (Fieldnotes from Batticaloa, June 1992).

\section{Notes}

1. The author acknowledges the financial support of the Social Sciences and Humanities Research Council of Canada and the Graduate School of Cornell University. A version of this article was presented on a panel cosponsored by the Shastri Indo-Canadian Institute and the South Asia Council of the Canadian Asian Studies Association. I wish to thank Bruce Matthews of Acadia University and Richard
Harmston of South Asia Partnership for pulling the panel together. For security reasons, I have maintained the anonymity of those individuals who were interviewed for this article. $I$ am in their debt and remain encouraged by their dedication and integrity in the face of adversity. I am solely responsible for the views expressed in this article.

2. In summary, government military action may be recorded as follows: 1) 1983-August 1987, Sri Lankan military engagement; 2) August 1987-March 1990 IPKF engagement; and 3) June 1990 - present, Sri Lankan military forces/ pro-government Tamil paramilitary engagement.

3. The U.S. Committee for Refugees estimates that more than 210,000 fled to the south Indian state of Tamil Nadu and that 700,000 are displaced within Sri Lanka (News release, November 12, 1991). For a general discussion of displaced persons in Sri Lanka, see: Jennifer S. Thambayah, "The Displaced in Sri Lanka: The Relevance of International Humanitarian Law." Unpublished paper, 1992.

4. Jonathan Spencer, ed., "Introduction: The Power of the Past" in Sri Lanka: History and Roots of the Conflict (London and New York: Routledge, 1990), 10.

5. Personal interviews, Sri Lanka, May-June 1992.

6. Ganath Obeyesekere, "The Origins and institutionalization of Political Violence" in SriLanka in Crisis and Change, edited by James Manor, (London and Sydney: Croom Helm), 153-74.

7. Determination of popular sentiment in a war zone is problematic, however. Attitudes and allegiances are context-dependent according to who is asking the question and which group is "in control" at the moment. As a resident of the East Coast explained to me, "there is always undying support for which ever group is holding a gun to your head".

8. For details, see Rajan Hoole, D Somasundaram, K. Sritharan and Rajani Thiranagama. The Broken Palmyra, The Tamil Crisis in Sri Lanka: An Inside Account (Claremont, CA: The Sri Lanka Studies Institute, 1992).

9. EPRLF: Eelam People's Revolutionary Liberation Front. EROS: Eelam Revolutionary Organization of Students. PLOTE: People's Liberation Organization of Tamil Eelam. TELO: Tamil Eelam Liberation Organization.

10. The first incident is reported in the University Teachers for Human Rights (UTHR) Jaffna, "The Debasement of the Law and of Humanity and the Drift Towards Total War," Report \#8 (August 28, 1991). It was also recounted to the author in the course of discussions with residents of Batticaloa. The murder of the policemen is reported in Amnesty International, "Sri Lanka - the North-East: Human Rights
Violations in a Context of Armed Conflict." (London: Amnesty International, 1991). A statement attributed to the vice-chancellor of the University of Jaffna, dated November 16,1992 disclaims any university connection with the publication "Human Rights in Sri Lanka" by the University Teachers for Human Rights - Jaffna Branch. This may be more indicative of the intimidation that rules the North than the legitimacy of the UTHR (Jaffna), a group that has consistently reported on human rights abuses in the North and North East. The murder of Professor Rajani Thiranagama (Department of Anatomy, University of Jaffna) in September 1989 for her refusal to accept the abuses of any military or paramilitary organization is but one example of such intimidation (see note 8). Ultimately, the credibility of any material is determined by critical and politically sensitive scrutiny. All details derived from UTHR (Jaffna) publications in this article are independently confirmed in other sources. The most recent UTHR (Jaffna) publication of which I am aware is "Report \#11: Land, Human Rights and the Eastern Predicament" (Thirunelvely, Jaffna: UTHR (Jaffna), April 15, 1993).

11. This was brought to my attention by Dennis Cole, senior analyst, Immigration and Refugee Board of the Government of Canada.

12. Eelam People's Democratic Party (EPDP) is a Tamil paramilitary group that splintered off from the EPRLF in 1987.

13. For details, see A.K. Menon, "The Other Battle field," India Today (October 15, 1991): 99; The Hindu(Madras) (September 6, 1991): 1; Frontline (Madras) reprinted in Christian Worker (Colombo), (2nd and 3rd quarter 1991):xvi. For an excellent analysis see: Bruce Matthews. "Trouble in Sri Kotha: Strains and Perils of Democracy in Sri Lanka," Roundtable 322 (1992): 215-27.

14. Christian Worker (January 1990): viii-x.

15. Interestingly, this is a view that was candidly shared by both military and paramilitary leaders.

16. Unfortunately, the most current demographic information is the 1981 Census. This does not indicated the mass movements of peoples since then. Nonetheless, the data do suggest the differences between these areas and the rest of the country.

17. See K.M. de Silva, Managing Ethnic Tensions in Multi-Ethnic Societies: Sri Lanka, 1880-1985 (Lanham, MD: University Press of America, 1986): 228 and "Sri Lanka's Muslim Minority" in Ethnic Conflict in Buddhist Societies: SriLanka, Thailand and Burma edited by K.M. de Silva, Pensri Duke, Ellen Goldberg and Nathan Katz (Boulder, Colorado: Westview Press, 1988).

18. Ameer Ali, "Sri Lanka's Ethnic War: The Muslim Dimension," Pravada, 1, no. 11 (November, 1992): 5-7; University Teachers for Human Rights (Jaffna), "The 
Debasement of Law and of Humanity and the Drift Towards Total War," Report "8, (August 28, 1991): 53; and personal interviews.

19. U.S. Committee for Refugees, Sri Lanka: Island of Refugees, prepared by Court Robinson (Washington, D.C.: U.S. Committee for Refugees, 1991): 25-28.

20. Figures from Sri Lanka Monitor (July 1991); and the U.S. Committee for Refugees, $S r i$ Lanka: Island of Refugees (1991), 25-28.

21. Island International, (September 9, 1992), 4.

22. Mary Anne Weaver, "The Gods and the Stars," The New Yorker (March 21, 1988), 67; See also Rodney Tasker, "Brink of Civil War..." Far Eastern Economic Review (February 21, 1985), 39.

23. K.M. de Silva, "Sri Lanka's Muslim Minority" in Ethnic Conflict in Buddhist Societies: Sri Lanka, Thailand and Burma, edited by K.M. DeSilva et al. (Boulder, Colorado: Westview Press, 1988), 211.

24. Ameer Ali, "Sri Lanka's Ethnic War: The Muslim Dimension," Pravada 1, no. 11 (November 1992): 5-8.

25. Shantha J.R. Pieris and Jeanne Marecek, "Report on the Welikanda Massacre." Unpublished report commissioned by the International Centre for Ethnic Studies, Colombo, May 11, 1992; and Sunila Abeysekera, "Report on the Massacres in Karapola, Muthugala and Alanchipothana." Unpublished report, INFORM, Colombo. May 15, 1992. See also Amnesty International, "Sri Lanka: An Assessment of the Human Rights Situation," (February 1993), 9-10 (AI Index: ASA 37/1/93).

26. Alleged army massacres include the Mahilanthanai massacre on August 9, 1992. INFORM, Sri Lanka Information Monitor, Situation Report September 1992, 14 and February 1993, 14; the murder of 100 Tamil civilians near a refugee camp in Amparai in June 1990 and the massacre of eighty-three people in two buses on the MannarVavuniya Road: U.S. Committee for Refugees, Island of Refugees (Washington: USCR, 1991), 16, 22; the Kokkaddicholai massacre in Batticaloa in June 1991 [British Refugee Council, Sri Lanka Monitor, March 1992, 3 and January 1992, 1.

Alleged LTTE massacres include the murder of at least ten Muslims who were separated from fellow passengers on a train in Batticaloa in July 1992. Amnesty International, "Sri Lanka: An Assessment of the Human Rights Situation" (London: Amnesty International, 1993); the massacre of 200-300 TNA conscripts during LTTE's entry into Batticaloa in December 1989. University Teachers for Human Rights, Jaffna, "The Debasement of the Law and of Humanity and the Drift Towards Total War." Report "8 (August 28, 1991); the massacre of more than 100 police officers who surrendered to the LTTE in June 1990. Amnesty International, "Sri Lanka-the North-East: Human Rights Violations in a
Context of Armed Conflict" (London: Amnesty International, 1991); the Anuradhapura massacre of 150 people in May 1985 and the Dollar and Kent Farm massacres in 1984. More recently, the LTTE has been accused of the massacre of 120 Muslim men and boys at prayer in Kattankudy and the massacre of 173 sleeping children, women and men in Eravur in August 1990 . It should be noted that observers on the East Coast are not convinced that the LTTE was in fact responsible for the latter two massacres.

27. A view shared by the authors of the following: University Teachers for Human Rights, "The Politics of Destruction and Human Tragedy," Report \#6 (Jaffna: University of Jaffna, 1991): 22; U.S. Committee for Refugees' Sri Lanka: Island of Refugees, Washington, D.C.: U.S. Committee for Refugees, 1991, 2.

28. Amnesty International, "Sri Lanka-the North-East: Human Rights Violations in a Context of Armed Conflict" (London: Amnesty International, 1991), 17.

29. This incident has been reported in both local and international media. See, for example, Thomas Abraham, "Kill and Tell," Frontline (Madras) (May 8, 1992): 51-52.

30. INFORM, a local Colombo-based NGO has undertaken projects addressing this facet of the conflict. Particularly noteworthy is a recent rehabilitation project funded by South Asia Partnership. The project will establish a family rehabilitation centre with outreach activities throughout the island to address the severe psychological and physical effects of the violence. I am indebted to Anthea Mulakala, program officer of the Sri Lanka Canada Development Fund for bringing this to my attention.

31. Separate camps for displaced Muslims are located north of Colombo in Puttalam District.

32. Personal interviews, Colombo, May and July 1992. Similar incidents are noted in the 1991 US Committee for Refugees report.

33. Reported in INFORM, Sri Lanka Information Monitor, Situation Report (April 1993): 9.

34. Personal interviews, May-June 1992.

35. This was brought to my attention by a Sri Lankan newspaper reporter.

36. For example, INFORM reports, "Arrests of young Tamils continued to take place in Colombo with 17 youth arrested in Fort on the 8th of February supposedly because they did not have sufficient reason to be in Colombo. A young man named $K$. Shanmuganathan from Kytes lan predominantely Tamil inhabited island in the Northl was hacked to death at Bodhiraja Mawatha, Petah." Sri Lanka Information Monitor, Situation Report (February 1993): 16. Similarly in December 1992, the police detained for questioning over 500 Tamils from all the major towns in the south because their "explanation of being in the South appeared unacceptable to them." INFORM,
Sri Lanka Information Monitor, Situation Report (December 1992): 10.

37. For example, following the November 16, 1992 assassination of the Commander of the Sri Lanka Navy, Amnesty International reports that "the police detained over $\mathbf{3 0 0 0}$ Tamil people living in the south and screened them for connections with the LTTE. The majority were released within a few days." Amnesty International, Sri Lanka: An Assessment of the Human Rights Situation, February 1993 (AI Index: ASA 37/1/93).

38. For example, one amendment provides for the issue of receipts to relatives of persons arrested in cordon and search operations only if a request is made. As Suriya Wickremasinghe, secretary of the Civil Rights Movement of Sri Lanka points out, "arresting officers may falsely deny that any such request was made [and] relatives may fear to make or may be intimidated from making such requests." For a brief discussion of the February 1993 Amendments, see the Civil Rights Movement of Sri Lanka, "Emergency Regulations-The Recent Amendments," E 03/2/93, February 25, 1993.

39. Ibid.

40. Figures from a 1985 survey conducted by the Madras Christian College, Department of Statistics cited in U.S. Committee for Refugees. Sri Lanka: Island of Refugees (Washington, D.C.: U.S. Committee for Refugees, 1991), 9.

41. 124 Tamils arrested in March 1992: SriLankan Monitor (March 1992): 2; over 100 Plantation Tamil youths arrested in Uva: Sri Lanka Monitor (January 1992): 3; see also Sri Lankan Monitor (November 1989): 3.

42. Personal interviews, Sri Lanka, May-July 1992.

43. Assassinations: Defence Minister Ranjan Wijeratne in March 1991; Vice Admiral Fernando November 1992. The Kayts land mine explosion killed Major General Kobbekaduwa, northern commander of the army, the security forces commander of Jaffna, the commander of the northern naval area and three senior lieutenant colonels. These assassinations have hindered the military's fighting ability in the North and East and exacerbated the ongoing friction between career officers seeking advancement (see Waruna Karunatilleke "Changing of the Guard," Counterpoint (April 1993): 30-31. JVP Infiltration: There is continued concern with JVP infiltration of the military, illustrated by the arrest of an army officer for helping the leader of the IVP escape to India. "Army Officer Charged with Helping IVP Leader," The Island (April 5,1992); see also the Sri Lanka Monitor (December 1991): 4. Loyalty of the Forces: Officially, it is estimated that between 3,000 $-4,000$ soldiers have deserted from military service; Sri Lanka Monitor (March 1992); 3; and The Island (June 1992). • 